\title{
3 Conspicuous and performative blackness as decolonial political branding against the myth of the post-colonial society
}

\author{
A case of the EFF \\ Rofhiwa Felicia Mukhudwana
}

\section{Introduction}

In the black-majority country that emerged from both colonialism and apartheid, and in the era of decolonisation wherein a significant number of voters are becoming black conscious, blackness is commodified, conspicuously performed and appropriated for various reasons including political identification. Although political parties' notions of blackness are substantially legitimate to use as an evaluation tool in political behaviour (Walters 2007, 13), there has been a paucity of scholarship on the use of blackness in political branding (Fuller 2010, 289). Political marketing research indicates that brands and branding are crucial elements in politics as they can be utilised in positioning party branding to differentiate themselves, to shape perception and to attain a competitive advantage (Pich \& Dean 2015). While scholars have examined political branding in Africa, fewer, if any, have focused on how branding targets citizens via racial, ethnic or class differences, particularly how blackness can/has been used as a political brand. Even fewer studies have approached blackness as a political branding from the perspectives of voters. In practice, however, post-colonial countries like South Africa (SA) are no stranger to racial and ethnic political branding. For example, the Azanian People's Organisation (AZAPO) emergent from the Black Consciousness Movement (BC) and the Pan African Congress of Azania (PAC) in SA were actually founded on the idea of black solidarity while the Inkatha Freedom Party (IFP) was and is still espoused by its ethnical alignment to the Zulu culture. What has been lacking is the theoretical and academic engagement of this phenomena, both in history and in its current incarnation within the "new" decolonial turn. While scholars acknowledge political branding, there is limited knowledge of the broader societal acceptance and understanding of political branding, particularly one that utilises the emotive realities of blackness (the black condition). The research question is: how would voters react to the emotional and performative branding of blackness as an ideological political position? The Economic Freedom Fighters (EFF) political party in SA is used as a case study.

DOI: $10.4324 / 9781003111962-3$ 


\section{The conceptual framework: blackness as concept}

Blackness is a multidimensional concept that refers to "the conception of what black subjectivity and identification signifies and symbolises in society' (Dei 2018, 119). It is both an identity and an experience - that is shared and contested. Blackness is contingent on different histories and specific geographies. Johnson (2003) called blackness an elusive signifier 'too slippery ever beyond the reach of one's grasp. Once you think you have a hold on it, it transforms into something else'. The notion of what constitutes blackness has changed over the years and through generations. It is both spatial and temporal. It is also theoretically disparate in meaning. For instance, Fanon, Ngũgĩ and Biko approach blackness differently. While Fanon and Ngũgĩ take the Pan-Africanist view of solidarity of the skin, Biko emphasises the (local) agency of the South African apartheid struggle and the black experience. In his case, the black experience being apartheid and the quest for liberation. In my definition today, blackness as experience refers to the treatment of race as sets of enacted behaviours of the lived experiences that are influenced by the socially constructed meaning of the perceived physical difference of "being" black under the structural conditions afforded in the particular geo-politics. This definition emphasises that the performance of race (blackness) is the result of both agency and structure. Race is defined by both the subject and the situation (Calmore 2005, 100). Thus, context becomes a key point in understanding notions of blackness. Blackness today is often tied to nationalism, ethnicity, tribe, language and location, especially within the South African context. Albeit simplified here, the definition of blackness is cumbersome because the black population is not monolithic. Hence, the meaning of blackness is neither uniform, nor singular, nor static. For example, Wright (2016) and Dei (2018) draw dichotomies between the blackness of the diaspora and what is termed "African blackness". As blackness is situational in its cultural performance, we delimit our analysis to the South African notion of blackness.

Biko's definition is contrary to Apartheid architects' treatment of race as fundamentally biological; see the Population Registration Act of 1950 that distinguish between the Bantu (of African tribe), the white and the coloured who is neither Bantu nor white. For Biko $(2017,52)$, being black is not a matter of pigmentation (skin colour) but a reflection of a mental attitude. $\mathrm{He}$ defined 'blacks as those who are by law or tradition politically, economically and socially discriminated against as a group in the South African society and identifying themselves as a unit in the struggle' (ibid). It cuts across the standard understanding of race to include the Native Bantus, the coloured and the Asiatics. Biko's definition is explicitly localised to SA (Epistein 2018, $100)$, further proving the geo-politics of the term blackness. This definition is therefore contrary to the universalism of the Pan-African notion that sought to unify blackness under a singular term of African Unity. The primary definer being the visible black body. As espoused by Ngũgĩ wa Thiong'o (2012), 
'Africa has to reclaim the black body with all its blackness' and that Africa is for Africans at home and abroad.

The consequence of the exteriority of the black skin cannot be denied. Skin colour alone is an inadequate yet sometimes socially, culturally and polemically necessary signifier of blackness (Johnson 2003, 19). On the passage, "look mommy, a negro", Fanon ([1952] 2008) describes a world that denies his inner life. In his view, whiteness (the structure) also constructs blackness - the superstructure and the base relatively hold the material influence to the type of blackness possible. Even Biko $(2017,55)$ observed, 'we recognise the existence of one major force in South Africa. This is white racism. It is the one force against which all of us are pitted'. Ngũgĩ wa Thiong'o (2012) illustrated how racism expresses itself with absolute "certainty" in profiling blackness based on the colour of the skin. The certainty that can condemn one to an early death as the situation is with the killing of black lives in America by the police. 'The certainty is based on a negative profile of blackness taken so much for granted as normal that it no longer creates a doubt' (Wa Thiongo 2012). Lewis Gordon $(2015,49)$ calls this "epistemic closure" which closes off efforts at further inquiry. Such is the cause of an overdetermined representative identity that is commanded and declared from the exterior. Fanon ([1952] 2008, 93) laments that 'I am overdetermined from the exterior. I am not the slave of the "idea" that others have of me but of my appearance'. This brings truth to the paradox of the hypervisibility and oblivion of blackness. That I am hyper-visible in my representation of all that is black but within the oblivion of who I truly am. This, according to Gordon $(2015,48)$, causes the erasure of the black experience as 'black experience suffers from the failure to bridge the gap between subjective life and the world'. What of experience then when the black's lived life is superseded by the appearance of namelessly and ahistorically just being black.

Biko adds a psychological criterion to blackness (Epstein 2018), which meant at the time the identification with the struggle against racism. This being the mental attitude of defiance against the inferiority complex of coveting whiteness. Today, it could simply mean feeling and acting black (agency) - thus discerning the performative nature of blackness as lived experiences which I seek to emphasis on this chapter. On the question, what do blacks want? Fanon and Biko differ in explaining what is withheld by the white system. For Fanon ([1952] 2008) what is withheld by the white system is the failure of mutual recognition as human. So blacks are dehumanised in the zones of non-being. Biko accepts but takes it further that what is withheld and sought by blacks is agency. For him, the distinction between whites and blacks is the capacity to act (Epstein 2018). Black agency means the reconstruction of the tools of blackness (Calmore 2005, 109).

Costa Vargas $(2006,476)$ defined blackness as a result of two types of processes. The first process is as a result of racialisation emanating from hegemonic institutions and practices, such as apartheid (and colonialism). I shall refer to this as "structured blackness" even when the dominant concept 
is systematic racism. The second refers to blackness as a result of our own agency of resistance, pride, hope and lived experience. I shall refer to this as "black agency" as reinforced by Biko black consciousness. This is the aspect of blackness that is ratified, packaged, commercialised, marketed, branded and performed. This duality of the meaning was observed by Stevens, Bell, Sonn, Canham and Clennon (2017) who defined blackness (1) as the consequence of being made black in the world by the others and (2) as a process of self-definition (self-agency). In exploring the negotiation of EFF's blackness as political branding by voters, it should be poised to observe the negotiability between these two processes of "becoming" black in SA.

\section{The theoretical framework: blackness as performance}

Blackness is the undeniably experience of black people, but it is also a restorative performance. Blackness as performance refers to how blackness is signed and embodied in the everyday life (for us, in politics). Performance theory emphasise that we invent bodies with meaning. Although theories of performativity focus primarily on the performance of gender, Johnson $(2003,19)$ engages a discussion about the performativity of race. Blackness offers a rethinking of performance theory by forcing it to ground itself in praxis such as racially oppressive systems (ibid). For example, Manthia Diawara characterises black performance studies as examining 'several interrelated notions, among them that "performance" involves an individual or group of people interpreting an existing tradition reinventing themselves in front of an audience, or public' (Calmore 2005, 109).

Rather than being innate, race is only real to the extent that it is performed. The recognition of the performance nature of race and identity opens the possibility for contesting their reified status which calls into question what it means to be black and the degree of blackness that is politically acceptable and that which is not. The concept of black authenticity implies the possibility of faking. The contestation is on the dichotomy between lived blackness and its representation. The authenticating of blackness is an attempt to secure a particular attribute of blackness. It is performed in order to circumscribe the parameters of inclusion and exclusion. In so doing, it becomes a contested political term, sometimes seeking to exclude the middle class, femininity and homosexuality for example. Despite Stuart Hall having said blackness has no necessary class belonging, 'class represent a significant axis and divisiveness within black communities' (Johnson 2003, 22). Authentic blackness is often associated with the poor working class, rendering black middle class as inauthentic and apolitical. Black economic mobility is said to breed assimilationists and race traitors who becoming politically and ideologically white, i.e. adopting white politics. This is a misnomer because it is the structural conditions that breed a particular type of blackness and once those conditions are removed in upward mobility so will the particular form of blackness leading to the pluriversality of blackness, each authentic in its own kind. 
Performance does not foreclose the discursive signifiers that undergird the terms of its production (Johnson 2003, 18). This means that 'externally imposed racial categorization remains an important part of the script' (Calmore 2005, 109). The performativity of blackness is externally influenced by two gazes: the hegemonic white gaze and the black gaze (Canham \& Williams 2017, 24). Both gazes attempt to homogenise blackness into predictability and stagnation. Black identity is often performed against a backdrop of white narratives. According to Sithole (2016), 'the white gaze is hate of the black subject'. The white gaze is systematic and operationalised by authoritative discourses, legal injunctions and numerous socio-political apparatus and practices - that control, interiorise and negate blackness. Accordingly, the white gaze seeks to discipline blacks, reminding them that despite democracy and increasing black mobility, white supremacy and white correctness remain uncontested. White hegemony is maintained by black self-disciplining into performative expectations of whiteness. The black gaze however does not gaze back at whiteness (although starting to), but rather at other blacks performing "a black-on black surveillance". Canham and Williams (2017) concluded that the black gaze negotiates blackness in terms of three indicators: physical identity, performance and class (discussed in previous sections).

Blackness as confirmative performance posits that one claims membership within the social group. This aligns with Biko's delineation that 'black consciousness is in essence the realisation by the black man of the need to rally together with his brothers around the cause of their operation'. Performing blackness is increasingly complex when issues of immigration and race intersect. The other relates to bi-racialism. Establishing and maintaining solidarity is a challenge for the black diaspora in the United States. The same could be the case in South Africa. While some immigrant blacks may emphasise their solidarity with the locals, others prefer to distance themselves from the "blackness" of the locals. However, some locals feel that black immigrants are replacing them (in economics and in culture).

Performance in politics is associated with populism. In application of the performance theory, this chapter cannot ignore the discussion of the EFF brand of politics built around the politics of spectacle reminiscent of populism. Populism can be defined 'as an ideology which pits a virtuous and homogenous people against a set of elites and dangerous others who are together depicted as depriving the sovereign people of their rights, values, prosperity, identity and voice' (Abertazzi \& McDonell 2008, 3). When it comes to blackness as political branding, this would be pitting blackness against the white system. There is significant literature around various types of populism in South Africa: populism as political communication styles (Mukhudwana 2020), populism as performance (Nieftagodien 2015; Mbete 2016), religious populism in politics (Forster 2019), populism as policy discourse looking at the radicalisation of land reform (Zukowski 2017) and charismatic populism focused on liberation movements (Melber 2018). What is posited on 
this chapter is closer to racial/ethnic populism. Racial or ethnic populism appeals through performance and self-presentation to a particular segment of society as the "pure" people. The departure, however, is on grounding this study on blackness as political branding and on the performativity of both blackness and branding (rather than on populism as theory).

\section{The literature review}

\section{Blackness as an ideological political brand}

In political communication, political branding is based on the principle that political parties can be managed as brands (Milewicz \& Milewicz 2014). The implication is that brands and branding are a crucial element in politics. Political parties can use positional branding to differentiate themselves, to shape perception and to attain a competitive advantage (Grimmer \& Grobe 2017). A brand is a multidimensional construct with tangible features like trademark, names, colours and logos, and intangible features like behaviour (performance), relationships, history, experience and heritage (Milewicz \& Milewics 2014, 236). These work together to construct the image and reputation of the political party and its leaders (Grimmer \& Grobe 2017). Political parties embrace branding for its value towards long-term relationships with voters. Brands are complex constructs, co-created and co-managed by many actors. The media is coming to accept political branding as a multifaceted part of normal politics. While scholars acknowledge political branding, we have limited knowledge of the broader social acceptance and the understanding of political branding.

In this section, I explain ideology positioning as an element of political branding as an act of performance or self-presentation. The success of a brand depends on the efficiency of appropriating referent systems that are not already appropriated by competitors (Serazio 2017, 230). The same is true for political branding. Political parties face a similar challenge of finding brand differentiation that is not yet colonised by others. This chapter identifies the branding positioning of the EFF within the concept of black radicalism which is no longer appropriated amidst the myth of a rainbow South Africa. Even though black radicalism is not new to South African political ideologies, its reappearance in the "post-apartheid" is a strong differentiation factor for the EFF. However, during the apartheid times, this ideological positioning was inherent and not performative or invoked as it is now. Granted, within the EFF's brand positioning that apartheid is not over, a counter-argument can be made that a black radicalism ideology today is not invoked (as a ghost of the past) or performed but a necessitated lived reality.

Branding in this chapter is approached mainly from the point of positioning. Brand positioning is an organised system for finding a window in the mind. In simple words, brand positioning is about putting a brand first in a 
customer's thought process against all other related or competitive brands. A political party not only has to position itself as being unique but must also position its uniqueness on top of all other political parties and at the forefront of voter's discourse. They must also attach an emotion to that uniqueness. Therefore, the manner in which a political party positions its brand in the political marketplace is crucial. It seems in political branding, credibility is based on emotional implications rather than policy orientation, political performance and issue positioning. This means that what a political brand means or represents (sign value) is divorced from the material referent of what it does (use value). As such, the socio-political and cultural positioning of brands is becoming more paramount than their functional worth (Serazio 2017, 226).

Blackness as an ideological branding can bring forth a sense of belonging for voters and communicate certain values. The concept of ideology was coined by Destutt de Tracy in 1976 in reference to 'the science of analysing ideas' (O'Reilly 2006, 264). Later, ideology came to 'characterise an extreme political body of ideas' (ibid). Such is the definition reinforced in this text. Ideology has come to reflect a wider scope of application inclusive of class, race, gender, sexual orientation and others. A political party can position itself within a selective range of issues in a certain ideological continuum. Ideological political branding is ruled by two interrelated aspects. Those are hot issues and emotions. Emotion rather than reasoning is favourable in political branding. This is because politics is subjective as opposed to most products whose utility value can be proven or disproved. The emotionalising of political ideologies and their related issues and policies often leads to political polarisation - which inherently makes politics a competition with winners and losers, friend and foes, pure people and the corrupt elite.

The positioning of issue positions (and even the ideological brand itself) can be performed for attaining hypervisibility (brand awareness). Such is the domain of the EFF party which follows an issue-based model that tends to successfully position it on top of the spotlight. In political branding, this is how issue branding works:

the voter must be aware of the issue; hold an attitude towards it; understand the policy stance of the political parties towards the issue; and vote for the party that most closely matched his or her view on the issue.

(Dean, Croft \& Pich 2015, 21)

In general, citizens gravitate towards universal issues such as health, crime and the economy, for example. In South Africa, issues such as land, racism, economy, service delivery, employment and labour hold prominence in politicking, in the media and in citizen discourses. The success of a political brand can be measured by the effectiveness to which it is perceived better able to respond to key issues at the time. So issue management and issue positioning are essential elements of political branding. 
What is considered in blackness as political branding are three types of blackness: (1) cultural blackness (popular culture, tradition, everyday life) (Collins 2006), (2) economic blackness in reference to class and the position of blacks in the economy (Canham \& Williams 2017) and (3) political blackness relating to black issue politics (Walters 2007; Sithole 2016). Cultural blackness, political blackness and economic blackness can work together and reinforce each other in designing a coherent political campaign. However, contestations or discrepancies among cultural, political and economic blackness are possible. For instance, Walters (2007) described the contestation between Barack Obama's cultural blackness and his political blackness. He argues that although Obama was able to prove his cultural blackness in terms of skin colour and lived experience, he was not able to prove his political blackness in his presidential campaign because he chose to remain race-neutral in policies and issues. Similarly, white media has attempted to display a discord between the EFF's political blackness and economic blackness on the bases of class, the affluence of their education and their conspicuous consumptions.

I will expand a little on political blackness. First, I make reference to Sithole's (2016) concept of the "white liberal façade" of liberty. He argues that the concepts such as freedom, justice and equality are determined outside the black subject. They apply primarily to whiteness as a category that is humanised. They remain external and outside the political experience of most blacks. As long as the black is dehumanised in the zone of non-being, they will remain outside the practical application of the white liberal façade. Because of the negative consequences of Apartheid, the trust of black people is determined by the political parties' willingness and ability to represent black-interest issues in the political system. Black issues are those specific to black voters, particularly those which they feel disproportionately represented or unfairly treated. This projection is what black voters will vote for as they hold a decisive variable in political identification, alignment and voting in South Africa.

Blackness in political branding is seen as an identification marker of black resistance, agency, political consciousness and black affirmation. This is what is packaged, performed and branded as political capital. For example, Bourdieu (1986) identifies cultural resource/political capital as a status generating tool that is projected in three ways: (1) embodied (status-making taste, skills and practices), (2) objectified (status-making objects such as homes, cars and clothing) and (3) institutional (formal status markers such as education and occupation). Blackness in SA politics is not only an ideological maker or social justice, but also a status marker of black consciousness, political consciousness, of education - as in an avid reader of political literature, decolonisation and radicalism. So political blackness does not only identify the political party, but also the voter who associates with the political party. 


\section{The chronological trajectory of black issue politics in South Africa until the EFF}

South Africa became a democratic country in 1994 after the first majority election. Racial and ethnic populism is not a South African phenomenon but evident in many parts of the world were injustices against blacks have materialised. While ethic populism is dominant in African countries with fewer white settlers, racial populism seems prominent in white settler African countries. The purpose of this history section is to provide context to blackness as an ideological political position and to describe the development of black issue politics in SA. Such would illustrate the reincarnation of blackness in the post-1994 South Africa.

\section{The PAC (Pan-Africanism)}

The Pan Africanist Congress of Azania (PAC) was formed on 6 April 1959 with Robert Mangaliso Sobukwe as its president. The PAC was formed by a breakaway group of Africanists with an agenda of African Nationalism and continental unity inspired by Kwame Nkrumah. They felt betrayed by the multi-racialism adopted by the ANC within the frame of the Freedom Charter in 1955. Instead, they advocated for Africa for Africans. Pan-Africanism was both an ideology and a positional issue. In this, PAC envisioned a radical land redistribution policy and Africa-wide unity - with the slogan "Izwe Lethu" (Our Land). The other issue positioning was racial separatism, choosing to define a black by physical identity and also putting blacks as their primary concern. Black consciousness in the form of black agency was another issue that identified the politics of the PAC. The EFF has adopted the African nationalist issue position from the PAC. This is demonstrated by their position regarding the opening of African borders. That South Africa belongs to all black Africans, including black immigrants.

\section{INKATHA (ethnic traditionalism)}

The Inkatha Freedom Party IFP (Inkatha Yenkululeko YeSizwe) was founded in 1975 as the Zulu National Cultural Liberation Movement by Chief Mangosuthu Gatsha Buthelezi. The purpose was to promote the Zulu culture in the form of ethnic nationalism directly incorporated into the secluded Apartheid Bantustan political structures. As a political party, Inkatha 'established itself as a patriarchal movement that was rooted among the traditional leaders such as the amakhosi/izinduna in the rural areas of KwaZulu and Natal' (Sithole 2011, 1171). IFP was positioned as the internal struggle against apartheid after the ANC was banned which is incorrect because such Zulu nationalism reinforced the ethnic divisions imposed by the apartheid ideology of divide and rule. This kind of ethnic blackness was contrary to the ANC version of blackness based on unity of all non-whites. 


\section{AZAPO (black radical nationalism)}

The Azanian People's Organisation (AZAPO) was formed on 28 April 1978 following the student uprising of 1976. Azapo draws its ideology from the black consciousness movement espoused by Steve Bantu Biko and thus considers itself heir to the philosophy. Although membership was open to blacks, coloureds and Indians, the party was hostile to the participation of whites in the struggle. The founding manifesto of the EFF takes the same position. But over the years, the EFF is beginning to glaringly prefer a delimitation to black Africans and coloureds. The perception at the time was that Azapo was racist. In the 1980s, the party moved towards the intersection of class and race as ideological bases of mass mobilisation. Azapo came to believe that class divisions had taken place along racial lines in South Africa because of both capitalism and apartheid. Almost all these issue positions are the current base of the EFF.

\section{The EFF ("post"-apartheid black radicalism)}

The EFF political party was launched on 13 October 2013. Having adopted elements of various radical black liberation movements, the EFF presents itself as a unifier and a reincarnation of the legacy of black resistance. The EFF describes its ideology as "Marxist-Leninist-Fanonian" and also Sankarist, Bikoist and a vanguard of the working class and the poor. The political branding is positioned around the notion of a radical revolution focused on redistribution, economic liberation and empowerment (Horwitz 2016, 40; Founding manifesto 2013). They re-appropriate and perform symbolic black resistance. For example, the EFF re-appropriated signature red berets (from the Black Panther Movement) as struggle accessories while work-man and domestic overalls signal solidarity with working people (Nieftagodien 2015). The revival of (downloadable) struggle songs captures the essence of the revolution. The party invokes spirits of South African and African radical leaders. However, the EFF identifies with the most radical of leaders or elects to remember the most radical times of their leadership. For instance, the EFF wants to recover the history of Mandela as a fighter and commander-inchief of Umkhonto weSizwe (MK). They also chose to remember Winnie Madikizela's legacy as a delinquent of the apartheid government. This rewriting of the political history contrary from the white narrative is an active decolonial tool of epistemic resistance and re-remembrance.

The EFF branded message is that the ANC has abandoned its historical blackness revolution and socialist mandate. The performance of this brand position is in demonstrating to the public the incompetence and corruption of the ruling class. The aim is to unravel the ANCs political hegemony and present it as a crisis, breakdown and a thereat to the people. In taking the advantage of pre-existing grievances, the EFF captured those disgruntled (by unemployment, expensive public services, cut-offs, loadshedding, 
evictions, etc.). According to the EFF, the struggle against the white system is not won. Political liberation is useless without economic freedom. Even '20 years after the attainment of formal political freedom, black people of South Africa still live in absolute mass poverty, are landless, their children have no productive future' (EFF 2013). Twenty-five years on, black people remain landless and at the margins of economic production and participation (EFF 2019). The ANC government reproduces the inequalities and imbalances of the past by not doing much to transform the economy. Instead, their naivety of wanting to be seen as liberal has contributed to uncritical adoption of neo-colonial policies that have stifled development. The catchphrase of "Economic Freedom in Our Lifetime" portrays an urgent mission. Same with the 2019 manifesto, "Our Land, and Our Jobs Now". The urgent emphasis on "Now", according to the 2019 EFF Manifesto, is "informed by the fact that 25 years is a rather long time for any political party to keep making empty promises'.

The EFF issue positions include: (a) land expropriation without compensation, (b) nationalisation of mines, banks and related sectors of the economy - meaning state-owned enterprises must not be privatised (thus an attack on white monopoly capital), (c) capacitating government to self-function without tenders (thus attack on tenderpreneurs), (d) free education, healthcare, houses and sanitation (as a champion of the poor), (e) job creation and good working conditions (thus performative supporting of Marikana), (f) development of the African economy (thus Pan-African nationalism) and (g) corruption-free government. These are issue positions around blackness. The authenticity of these policies is beyond the scope of this chapter. But I aim to explore the reception of these issue positions on Twitter among voters.

Because of his charismatic character, EFF Commander in Chief continues to dominate the mainstream media (Mbete 2016) and social media (Mukhudwana 2020). This is because of his fiery and emotive rhetoric speeches delivered among the masses, not to mention quotable and memeble catchphrases accompanied by dissing the enemy in sometimes funny utterances. As a champion of the people, Julius Malema relies on another political communication style that I have identified as Revolutionary youth radicalisation which mobilises the youth into political positionality and political action within an ideology of "blackness", "us" against "them" (Mukhudwana 2020).

In the beginning EFF has positioned itself within the Left (Horwitz 2016, 65). This position has been uncontested since the fall of the Apartheid government. Even historical, radical left and black revolutionist parties, such as PAC and AZAPO, had moved to the centre if not the right post-1994. However, the rise of populism is dissolving the distinction between rightand left-wing politics. For instance, it is no longer clear whether the EFF is correctly described as lefties politics as it is gradually moving to right-wing ethnic nationalism. 


\section{Methodology}

Using imbizo/Imbadu/Lekgotla/Khoro as an indigenous research methodology, I attempt to answer the research question by decoding the process of the social shaping of blackness in the EFF twitter account. Imbizos can be described as a rhetorical platform used by indigenous communities to resolve community issues and build community cohesion (Mukhudwana 2015). It is a common practice for a chief, headman or any other community leader to convene a community meeting with a view to discussing issues of common concern and interest. The rules and structure of the discussions are set by the communities in question. Khoro/Imbizo as a rhetorical platform can be enacted within an online communicative space to resemble online discussions. It is not the first time that this method has been used within an online environment. Seti-Sonamzi (2019) uses the method within its IsiXhosa version of imbadu. The online communities that go to the EFF twitter page to discuss notions of blackness are similar to the community that goes to the khoro where issues are discussed and negotiated. The point is to draw on the co-creation of knowledge (on this case, notions of blackness) between the political party and its constituents. I argue that khoro expands on phenomenology which does not sufficiently recognise the diversity and the fluidity (negotiability) of knowledge production. As phenomenology is more concerned with the individual and his/her feelings and knowledge, khoro is more concerned with the community of individuals and the rhetoric through which knowledge is created, negotiated and modified. The social shaping of blackness is thus created through this process of negotiation. The social shaping of blackness is essential as blackness is not monolithic or singular. The South African notion of blackness is diverse and thus the positioning of blackness is a perpetual co-created negotiation (now taking place in cyber space). This is what I imply by the term social shaping' of (political) blackness.

The aim of the chapter is to explore the negotiation of blackness as an ideological political branding of the EFF and to conduct a reception analysis of blackness as an ideological political branding by voters on twitter. However, I delimited my analysis to two EFF black issue positions in the year 2020: (1) de Klerk is racist and (2) white monopoly capital. On advanced Twitter search, I punched each of the above issue positions at a time and added EFF as an additional keyword. A qualitative virtual auto-ethnography methodology (khoro) was used and a purposive sample of tweets was selected. Purposive sampling, also known as judgemental sampling, was deemed suitable as it allowed the researcher the ingenuity to select a series of tweets that best represent each issue position (Wagner, Kawulich \& Garner 2012, 93). The period of study is delimited to year 2020 as two of the issue positions (2 and 3) were matters of EFF political performance during SONA 2020 which took place on 13 ruary. The EFF seems to use SONA to set the stage for the performance of their issue positions annually. Certain questions will 
Table 3.1 Analytical questions

\section{Blackness as concept (about voters)}

- What is withheld by the white system (mutual recognition of humanism or the agency of the black to act)?

- Blackness as biology or as lived experience or as performance?

- What black lived experience is identified in the tweet?

- Pan-African vs local blackness - which local blackness?

- Which process of blackness is dominantly discussed? Structural blackness (the pain) or black consciousness (the pride)?

- Enabling self-political identification - how is political blackness used by a voter to identify himself/herself?

\section{Performance of blackness as branding (about EFF)}

- Brand awareness - Are voters aware of the blackness branding of the EFF?

- Brand Image - How do they judge it (good/necessary or bad/useless)?

- Brand authenticity - Do they see it as noble lived black experience or empty performance (populism)?

- Enabling self-political identification - How is $\boldsymbol{E F F}$ brand used by a voter to identify himself/herself?

\section{Black issue positioning (and EFF performances/spectacles around issue)}

- Reception of issue 1 racism de Klerk

- Reception of issue 2 white monopoly capital

guide the selection and the analysis of tweets in each category even though none of the categories are mutually exclusive (they are intertwined). These questions emerged from the conceptual framework, theory and literature. A thematic analysis will follow the categorisation of these questions in addition to outliners found. For future studies, these questions could produce a quantitative analysis on a larger pool of data (Table 3.1).

\section{Findings and discussion}

\section{Reception of issue 1 racism de Klerk}

The selection of the de Klerk issue position by the EFF is pertinent as best able to integrate the racial mood of the country and the EFF's "role" in it. Frederik Willem (FW) de Klerk is the last president of the apartheid government (1989-1996) and the deputy president of SA (1994-1996). Jointly, with first democratic SA president, Nelson Mandela, de Klerk received a Nobel Peace Prize for "giving up" apartheid, releasing Mandela and ushering a universal suffrage inclusive of blacks. Conversely, he is critiqued for complicity in gross human rights violations and massacres during his administration. On 2 ruary 2020, marking 30 years since the unbanning of liberation political parties, de Klerk argued in SABCnews TV interview ${ }^{1}$ that Apartheid was morally wrong but not a crime against humanity: 'Genocide is a crime, apartheid cannot be for instance compared to genocide'... 
'more people died because of black on black violence than apartheid'. Performances: The EFF lobbied for the Peace Price to be revoked along with all his political credentials and privileges. Using aggressive delaying tactics and verbal attacks in parliament during the Sona, they demanded for de Klerk to be removed from chamber labelling with a "racist apartheid denialism". In addition, the EFF laid a charge against him for hate speech. A backlash against de Klerk and the ANC ensued following the aftermath of Sona.

The de Klerk issue looked like a polarising matter but it was not. The majority of voters were unanimous that de Klerk must be chastised and something ought to be done. They were just not convinced that the EFF went about it the right way in making the attack in parliament during SONA. Nonetheless, the division of the issue between two sides was visible. Tension was created along racial lines, with most blacks detesting de Klerk and most whites imposing the acceptance of de Klerk's apology. The white narrative is that the EFF is divisive and predominately vilify white people, @ ElizeVC, 16, 'somebody new to vilify... next week it will be another white person'. @Keith76167969 ( 18) tweeted, 'it's so predictable,EFF refuses to accept de klerk retraction in order to hold centre stage... and pursue their agenda of hate'. The assumption made is that EFF is racist. On the other hand, blacks felt as if their humanity is not mutually recognised when even their mass murder does not qualify as genocide or a crime against humanity, because they still do not qualify the category human.

There were several tweets that indorsed the EFF as the champion of the people against the ANC that abandoned its liberation struggle against apartheid and racism - which still exist in SA. For example, @NicKay ( 16) tweets, 'The ANC was protecting de Klerk, DA was protecting Ramaphosa, EFF was protecting people of South Africa. SONA 2020'. The tweet had $1.1 \mathrm{~K}$ likes. This is an ideological success for the EFF because it paints Ramaphosa and the ANC as sell-outs protected by the white system. In such case, no one is left to defend black people, but the EFF. @Nathi_Mfokajobe ( 18) tweets, 'As far as they were playing their politics, deep down I appreciate EFF for embarrassing de Klerk in front of the nation while ANC was kissing him'. This is a similar quote in the category of a backlash against the now useless apartheid apologist ANC. However, this tweet resembles another category of tweets which indicate that voters are aware of the theatrics of the EFF as political performance. For example, @ HonourableHloni tweets, 'the same people who called EFF populist for demanding de klerk's removal from parliament are applauding the American Bar Association for cancelling his talk on law and racism'.

The agreement among voters is that EFF's theatrical performances, though labelled populist, are effective in not only setting the national agenda, but also enforcing an experiential political reform or effecting other consequence regarding the issue. An additional tweet is, 'due to EFF characteristically known for militant, fearless and radical character - the nation was rudely forced to have a conversation about institutional racism, especially 
against white supremacists' (@Sam_Matiase, 16). These performances are deemed successful where others have failed to bring the black agenda to light and equally pressure for its resolution. @MelusiMaposa ( 16) tweets, 'does anyone still doubt the EFF's ability to set the national agenda? 2020 wasn't the first time de Klerk peddled his apartheid denialism. It's just the first time that EFF made him the focal point'. The PAC has brought this issue up on a number of occasions but did not successfully succumb it to the national discourse. Perhaps because fewer voters comprehend the PAC's current ideological branding position. Another issue performed by the EFF during the 2020 Sona is the WMC.

\section{Reception of issue 2 white monopoly capital}

The selection of the issue position of White Monopoly Capital (WMC) contributes towards highlighting the economic emancipation agenda of the EFF. So powerful is the catchphrase popularised by Bell Pottinger that it resulted in its own Wikipedia page which defines it 'as a controversial South African phrase used in contemporary political discourse to describe the continued economic domination of whites in post-apartheid SA'. It is powerfully posited as the real reason blacks remain systematically oppressed and enslaved to a marginal lived experience. Consider for example a black woman having to withstand inhuman domestic employment in order to pay rent, pay school fees and feed kids. Therefore, WMC is directly linked to the capacity of blacks to act (agency) in an anti-black capitalist system. What is confusing in the blackness branding is that this positioning implicates both the white system and selected blacks as agents of that system. Performance: EFF calls on the African continent to reject the WMC puppet Trevor Manuel as AU Envoy on a statement dated 13 April 2020. The EFF organised a well-attended \#EFFEskomMarch with the message that Pravin must go, Eskom must not be privatised and load shedding must fall.

The issue positioning of WMC is intricately positioned as the performance of various categories of players. One of such is the ANC government, within which President Ramaphosa and Pravin Gordhan, Minister of Public Enterprise, are the main villains. On the manifesto to Consultation Assembly, Malema said, 'When we formed the EFF, we knew that the will not allow for the nationalisation of the strategic sectors'. For this reason, "we have decided to go against Pravin". Another strong message went to Cyril Ramaphosa upon his election to the national assembly as president: 'we know your proximity to Oppenheimers. We've not elected Oppenheimers here...we are warning you president, we've not elected the Ruperts... once you listen to white monopoly capital, you must know that you are likely not to finish your term'. This is interesting because the EFF believe they have the power to inaugurate and topple SA presidents. The other agent of WMC in SA according to the EFF is STRATCOM media syndicates, who are mainly white-owned media responsible for publishing anti-black racism in addition to discrediting the EFF and its leadership. @naledimashishi tweets, 'So basically any journalist 
who publishes any article critical of EFF is now STRATCOM. EFF leadership cannot be criticized... if they are, it's a conspiracy by WMC'. STRATCOM was an organ of the Apartheid state propaganda. The third accused agent of WMC is white farmers who are unduly holding on to the land. For instance, Zukowski (2017) postulated that the discourse of land reform has been radicalised by the EFF in a race-based populist narrative of land expropriation without compensation. @SiyaNdlovu91 (Apr 16) tweets, 'EFF policies are strong on WMC...there is a pillar of land expropriation without compensation. It is not a compromise in the culture of the EFF'.

The issue of WMC among the blacks is polarised with others seeing EFF as a vanguard of the people saving them from expensive privatisation leading to the poverty of the poor against those who see it as an EFF agenda to secure corruptive looting of state agents through underhanded tenders. On one side stands proponents. @MzilikaziKADON1 (March 3) tweets, 'Ramaphosa said with his own mouth today that he is interested in selling some parts of Eskom. If EFF did not expose him with Jamnandas, Eskom as a whole was gone to the biggest WMC bidder'. And on the other side stands opponents. 'We know that Malema is using his EFF to fight his personal battle with Pravin in the name of fighting WMC'. Another voters' backlash against the issue position of white monopoly capital is with regard to EFF leaders' own proximity to capitalism and its aesthetics. @ chestermissing (May 10) tweets, 'Andile says the EFF represents white monopoly capital. Is he talking about comrade Breitling, Johnny Walker and Louis Vuitton?'. Even further critique refers to EFF's coalition with the Democratic Alliance in provincial and local government. @Vuyo17 (July 28) tweets, 'The EFF votes were sold to the racist DA. EFF is just a WMC scam to steal black votes'. What these critiques have in common is the dichotomy between the EFF performance of blackness as a brand which seems contrary to its lived/political experience. This brings into question the authenticity of the brand.

\section{The societal reception of blackness as political branding}

The ideology of the EFF is often put into question regarding blackness and class. For example, @Brandaan Huigen (28) tweets, 'So the EFF does have an issue with luxury lifestyles? Always thought it was ok to be Gucci-socialist. Maybe Sankara has finally become an inspiration'. This tweet reinforces the stereotype of associating authentic blackness with a lower class and frugality. Even though criticising the EFF, this voter is conscious of the EFF's ideology around class and blackness. Thus, even those who attack the EFF for racism are brand aware of its blackness.

There is general societal acceptance and understanding of blackness as political branding, what is frowned upon is the abusive utility of the emotive realities of blackness (the black condition) for cheap political capital. The weaponisation of blackness as a political tool. One tweet states, 'EFF doesn't care about your blackness. They use it for votes and a better life for themselves' (@Unathi_Kwaza, May 22)._Therefore, the genuine interest and care of the 
black masses become the authenticity marker leading to the legitimacy of the party. In addition, the claiming of the blackness branding is also used by voters to police the EFF's behaviour towards the black population. As the case has been with the defaming of black lawyers as incompetent. This is a unique tool for accountability.

Voters' acknowledgement that the black population in SA is not monolithic grounds the critique against the positioning of the EFF as the sole custodian of blackness. For example, @Makgatho18 (Oct 22) laments that most fighter's intellectual lethargy is indicated by the thinking that EFF has sole proprietorship of blackness and that any ideology that deviates from EFF's is racist. 'The minute you disagree with the views of the EFF members as a black person you are called coconut, sell out, house-nigger etc. Like they are the custodian of blackness' (@Sakhilemngadi,Sep 20).

The EFF is seen by proponent tweets as fighting structural blackness and cultivating black agency. As the case is with, @Ketso_4LIFE (Oct 11). The EFF 'teach us to be proud of our blackness, to be proud of our history and culture as Africans'. On the contrary, there were several tweets expressing discontent to what they consider to be intolerant racist behaviour suggestive of racial radicalism.

\section{Conclusion}

In this chapter, I attempted to observe the extent to which voters are conscious of blackness as the EFF political branding/strategy/ideology and to explore the general societal acceptance of the branding strategy. I can safely conclude that voters are aware of the blackness branding position of the EFF. The division is with regard to the brand image (favourable or negative). The brand image differed, issue by issue. Whereas issue 1 garnered a widely positive image, issue 2 was polarised. While the de Klerk issue position had capacity to tremble the rainbow nation as a myth of reconciliation in "post-apartheid" South Africa, the WMC positioning weakened the very concept of "post-apartheid" SA as the lived experiences of blacks remain unchanged, economically enslaved to the zones of non-being. There is general societal acceptance and understanding of blackness as political branding, what is frowned upon is the weaponisation of blackness as a political tool. A broad quantitative study could better validate this preliminary finding. Future studies could also look into \#PutSouthAfricansFirst in order to decipher the reception of the EFF's Pan-Africanist concept of blackness which is inclusive of all Africans contrary to Biko's concept of blackness as all people subjected to apartheid in SA (local) which exclude immigrant African blacks who did not suffer anti-black racism in SA. This complexity deserves a full review. I would conclude this chapter by stealing a well-posited tweet by @OwaseMzantsi (20 Nov 19), 'Politics is FICTION, politicians are ACTORS in a soapy called "string then along for POWER". Like all fiction, they have to adhere to a script, a narrative they have to push'. 


\section{Note}

$1 \mathrm{https} / / / \mathrm{ww}$ w.youtube.com/watch?v=VBE844vDkx4\&t=1339s

\section{References}

Abertazzi, D \& McDonell, D. (2008). Twenty-First Century Populism: The Spectre of Western Europe Democracy. United Kingdom. Palgrave Macmillan.

Azapo prides itself on paving way for new parties. 2 May 2019. SABC News www. sabcnews.com/sabcnews/azapo-prides-itself-on-paving-way-for-new-parties/

Biko, S. [1978] 2017. I write what I like. The 40th anniversary edition. South Africa: Picador Africa.

Bourdieu, P. 1986. The forms of capital. In Richardson, J. (Ed). Handbook of Theory for the Sociology of Education (pp 241-258). Westport, CT: Greenwood.

Calmore, J.O. 2005. Whiteness as audition and blackness as performance: Status protest from margin. Washington University Journal of Law \& Policy, 18(6): 99-128.

Canham, H., \& Williams, R. 2017. Being black, middle class and the object of two gazes. Ethnicities, 17(1): 23-46.

Collins, P.H. 2006. New commodities, new consumers. Ethnicities, 6(3): 297-317.

Costa Vargas, J.H. 2006. Black radical becoming: The politics of identification in permanent transformation. Critical Sociology, 32(2-3): 475-500.

Dean, D., Croft, R., \& Pich, V. 2015. Toward a conceptual framework of emotional relationship marketing: An examination of two UK political parties. Journal of Political Marketing, 14(2): 19-34.

Dei, G.S. 2018. "Black like me": Reframing blackness for decolonial politics. Educational Studies: A Journal of the American Educational Studies Association, 54(2): $117-142$.

Economic Freedom Fighters Founding Manifesto: Radical movement towards economic freedom in our lifetime. Adopted by the Economic Freedom Fighters National Assembly on What is to be Done: 26 to 27 July 2013. Available: https:// effonline.org/wp-content/uploads/2019/07/Founding-Manifesto.pdf.

Economic Freedom Fighters 2019 Election Manifesto. 2019. EFF Online (online.), 6 May. Available: https://effonline.org/wp-content/uploads/2019/07/2019EFF-MANIFESTO-FINAL-1.pdf [23 May 2019].

Epstein, B. 2018. Biko on Non-white and black: Improving social reality. In G. Hull (Ed.), Debating African philosophy: Perspectives on identity, decolonial ethics and comparative philosophy (pp. 97-117). New York: Routledge.

Fanon, F. [1952] 2008. Black skin, white masks. Canada: Editions du Seuil.

Forster, D.A. 2019. State theology and the political populism? A Kairos critique of religious populism in South Africa. Journal of Church and State, 62(2): 316-333.

Fuller, J. 2010. Branding blackness on US cable television. Media, Culture and Society, 32(2): 285-305.

Gordon, L. 2015. What Fanon said: A philosophical introduction to his life and thought. New York: Fordham University Press.

Grimmer, M., \& Grube, D.C. 2017. Political branding: A consumer perspective on Australian political parties. Party Politics, XX(X): 1-14.Horwitz, D. 2016. The role of political branding in the success of the Economic Freedom Fighters (EFF). A minor dissertation submitted in fulfilment of the requirement for the award 
of the degree of Masters of Social Science: Political Communication. Faculty of Humanities. University of Cape Town.

Johnson, E.P. 2003. Appropriating blackness: Performance and the politics of authenticity. Durham, NC: Duke University Press.

Mbete, S. 2016. Economic freedom fighters' debut in the municipal elections. Journal of Public Administration, 51(3): 596-614.

Melber, H. 2018. Populism in Southern Africa under liberation movements as governments. Review of African Political Economy, 45(158): 678-686.

Milewicz, C.M., \& Milewicz, M.C. 2014. The branding of candidates and parties: The U.S news media and the legitimization of a new political term. Journal of Political Marketing, 13(x): 233-263.

Mukhudwana, R.F., 2015, 'Investigating communication management by government in the Kwa-Zulu Natal Province in South Africa', PhD thesis, University of Pretoria.

Mukhudwana, R.F. 2020. \#Zuma must fall this ruary: Homophily on the echo-chambers of political leaders' Twitter accounts. In M. Ndlela and W. Mano (Eds.), Social Media and Elections in Africa, (Vol. 2, pp 175-202). Cham: Palgrave Macmillan.

Nieftagodien, N. 2015. Economic freedom fighters and the politics of memory and forgetting. The South Atlantic Quarterly, 114(2): 447-456.

O'Reilly, D. 2006. Commentary: Branding ideology. Marketing Theory, 6(2): 2630271.Pich, C., \& Dean, D. 2015. Political branding: Sense of identity or identity crisis? An investigation of the transfer potential of the brand identity prism to the UK conservative party. Journal of Marketing Management, 31(11-12): 1353-1378.

Serazio, M. 2017. Branding politics: Emotion, authenticity, and the marketing culture of American political communication. Journal of Consumer Culture, 17(2): $225-241$.

Seti, V. 2019. On Blackness: The role and positionality of Black Public Intellectuals in Post-94 South Africa. Thesis submitted in accordance with the requirements of the degree of Doctor of Philosophy. University of South Africa.

Sithole, J. 2011. Inkatha freedom party - national freedom party dynamics in the KwaZulu-Natal Province. Journal of Public Administration, 46(3): 1169-1181.

Sithole, T. (2016). The Concept of the Black Subject in Fanon. Journal of Black Studies, 47(1), 24-40.

Sithole, T. (2016). The Concept of the Black Subject in Fanon. Journal of Black Studies, 47(1), 24-40.

Stevens, G., Bell, D., Sonn, C.C., Canham, H \& Clennon, O. 2017. Transnational perspectives on Black subjectivity. South African Journal of Psychology, 47(4) 459-469.

Wagner, C, Kawulich, B \& Garner, M. 2012. Doing social research: a global context. South African Edition. Berkshire: McGraw Hill Higher Education.

Walters R. 2007. Barack Obama and the politics of blackness. Journal of Black Studies, 38(1):7-29.

Wa Thiong'o, N. 2012. 10th Annual Africa Day Memorial Lecture, delivered at the University of the Free State, South Africa, May 25, 2012.

Wright, H.K. 2016. Stuart Hall's relevance for the study of African blackness. International Journal of Cultural Studies, 19(1): 85-99.

Zukowski, A. 2017. Land reform in the republic of South Africa: Social justice or populism? Werkwinkel, 12(1): 71-84. 